The Forgotten Jesuits: The Society of Jesus in the Duchy of Modena; Between Archival Memory and New Research Trends

Author: David Salomoni

Source: Engaging Sources: The Tradition and Future of Collecting History in the Society of Jesus (Proceedings of the Symposium held at Boston College, June 11-13, 2019)

Edited by: Cristiano Casalini, Emanuele Colombo, and Seth Meehan

ISBN: 978-1-947617-09-4

Published by: Institute of Jesuit Sources

Originally Published: March 1, 2021

https://doi.org/10.51238/ISJS.2019.15

Provided in Open Access by the Institute for Advanced Jesuit Studies at Boston College.

The Institute of Jesuit Sources, specializes in preserving, maintaining, and expanding for scholars around the world important texts and studies in Jesuit history, spirituality, and pedagogy.

Visit our website at https://jesuitsources.bc.edu 


\title{
The Forgotten Jesuits: The Society of Jesus in the Duchy of Modena; Between Archival Memory and New Research Trends
}

\author{
DAVID SALOMONI
}

\section{Introduction: The Global Goes Glocal}

In his recent work on pre-suppression Jesuit schools, Paul Grendler brings to light the impressive number of schools and colleges that the followers of Saint Ignatius established in Europe between the sixteenth and eighteenth centuries. ${ }^{1}$ The number of Jesuit educational institutions in this period can be counted in the hundreds, but surprisingly, even in light of the large amount of research that has been published on the Society's educational history, some historians claim that the real number of Jesuit schools and colleges is still to be definitively ascertained. ${ }^{2}$

This thus opens up the possibility for further investigation of an already well-exploited field of Jesuit history. However, if we are to do so, it is vital that a comparative approach is used that is able to take into account the many different realities that made up the heterogeneous and composite Jesuit galaxy, both in Europe and the rest of the world, as a global approach taken to the extreme risks ignoring sources considered too local in interest. The problem is that the "local" dimension of an object is not determined by the geographical size of the object being examined but by the use that is made of it in methodological terms. If we can use a case study as part of a wider perspective, exploiting its potential in methodological terms, it becomes possible to find a connection between the local and the global, enabling a better understanding of a given historical phenomenon as a whole.

For example, a sixteenth-century individual, in Italy, after birth, could grow up influenced by factors such as his social status, environment, religion, family, and birthplace (city or village), particularly as late medieval municipalism was still very strong in the early modern age. A dialect, a religious tradition, a political orientation could change from one village to another only a few miles away. Let us

\footnotetext{
${ }^{1}$ Paul Grendler, Jesuit Schools and Universities in Europe 1548-1773 (Leiden: Brill, 2019), 59. For an estimate of the number of Jesuit schools in Italy, see Sabina Pavone, "I gesuiti in Italia 15481773," in Atlante della letteratura italiana, vol. 2, Dalla Controriforma alla restaurazione, ed. Sergio Luzzatto, Gabriele Pedullà, and Eriminia Irace (Turin: Einaudi, 2011), 359-73.

2 These issues were discussed during a roundtable held at the 2019 Renaissance Society of America annual meeting, "New Directions in Jesuit Studies," in Toronto, March 4, 2019.
} 
assume that this sixteenth-century man decided to join the Society of Jesus and, after proper selection, went to Japan, China, India, Mexico, or secretly to England. His ties with his birthplace would continue, more or less consciously, to act in him. ${ }^{3}$

Another example of this dynamic can be found in the evangelization missions carried out by Jesuits in rural areas, both Italian and European. In the course of these missionary campaigns, in contexts normally considered as profoundly Christianized, traditions still steeped in paganism and magical elements emerged. To this effect, universal aspects linked to the relationship between man and the sacred emerge from the particularism of the Italian rural villas. Above all, we can grasp the link and similarities between the people of these domestic "indies" and those found as a result of the new geographical discoveries. ${ }^{4}$

These are just two examples of what I call glocality, a way of seeing and conceiving historical phenomena not only by admitting a link between the particular and the general but investigating it as an element in the evolution of history. But how can we tie this concept to the production of Jesuit archival memory?

In Italy, there are still a series of small historical archives containing important sources on Jesuit history. However, these archives are often noninstitutional Jesuit ones. They are municipal, parish, diocesan, and/or state archives, the contents of which have often been ignored by historians of Jesuit studies. Yet, the documentation preserved in these archives bears witness to the historical paths of many small colleges and boarding schools from several different perspectives: social, political, religious, cultural, and economic. They allow us to reconstruct that glocal, integrated dimension I mentioned earlier, and, if methodically charted, can improve our knowledge of the estimated number of Italian Jesuit boarding schools. As part of the comparative approach called for at the beginning of this essay, such "local" investigations should not be considered solely as a series of examples or

\footnotetext{
${ }^{3}$ On this vast topic, see Camilla Russell, "Becoming 'Indians': The Jesuit Missionary Path from Italy to Asia," Renaissance and Reformation/Renaissance et Réforme 43, no. 1 (2020): 9-50, and Liam Matthew Brockey, "A Passage through India: Jesuit Missionaries En Route to East-Asia 15701700," Revista de cultura 3 (2002): 115-25; Brockey, "Jesuit Missionaries on the Carreira da India in the Sixteenth and Seventeenth Centuries: A Selection of Contemporary Sources," Itinerario 31, no. 2 (2007): 111-32; Brockey, "'Largos caminhos e vastos mares': Jesuit Missionaries and the Journey to China in the Sixteenth and Seventeenth Centuries," Bulletin of Portuguese Japanese Studies 1 (2001): 45-72. See also Alexandre Coello de la Rosa, Jesuits at the Margins: Missions and Missionaries in the Marianas, 1668-1769 (New York: Routledge, 2016), and Emanuele Colombo and Marina Massimi, In viaggio: Gesuiti italiani candidati alle missioni tra Antica e Nuova Compagnia (Milan: Il Sole 24 Ore, 2014).

${ }^{4}$ On the topic of the domestic "indies," refer to Paolo Broggio, Evangelizzare il mondo: Le missioni della Compagnia di Gesù tra Europa e America, secoli XVI-XVII (Rome: Carocci, 2004); Valerio Marucci, "Paolo Segneri e le missioni rurali," in Paolo Segneri: Un classico della tradizione cristiana; Atti del convegno internazionale di studi su Paolo Segneri nel $300^{\circ}$ anniversario della morte, 1624-1694, ed. Andrea Fedi and Rocco Paternostro (New York: Forum Italicum, 1999), 141-53; Louis Châtellier, La religione dei poveri: Le missioni rurali in Europa dal XVI al XIX secolo e la costruzione del cattolicesimo moderno, trans. Idolina Landolfi (Milan: Garzanti, 1994).
} 
case studies but instead as mosaic tiles in which the general could not exist without the particular and vice versa.

This paper examines the local network of colleges and boarding schools in the Duchy of Modena between the sixteenth and eighteenth centuries in order to explore the potential of the duchy's archives for future research. My aim is to give an example of the aforementioned hypothesis, explaining how some, often unknown Jesuit sources contained in communal or ecclesiastical historical archives, can tell us much about the history of the Society of Jesus.

\section{Jesuit Schools, Convents, and Archives in the Duchy of Modena}

The political, social, cultural, and religious situation of early modern Italy is very well suited to this type of investigation. Between the sixteenth and eighteenth centuries, a patchwork of small- and medium-sized Italian states competed for the presence of various religious orders within their borders. The size of these states could vary greatly, from the almost nationwide dimensions of the Kingdom of Naples to the small lordships located on the banks of the River Po. ${ }^{5}$ The call of a religious order to one of these polities could be determined by different causes, including the need for social control felt by the post-Tridentine monarchs after the Great Italian Wars, pressure from certain social groups, or even personal preferences or family ties. ${ }^{6}$ The charism of some religious orders could better respond to the needs of some groups of people. The aristocracies of the mountain areas, for example, aspired to the same type of education the Jesuits offered to the urban aristocracies. However, these nobles often lacked the economic means to open a college run by the Society. For this reason, therefore, it was not unusual to invite a religious order that would be more willing to operate in peripheral areas, such as the Piarists.

Other institutions and governing bodies could also influence the arrival and distribution in certain territories of early modern religious orders and, consequently, of their archives. These institutions were represented mainly by the city councils and towns and villages. Among the tasks of these assemblies was the management of public finances (such as the city budget or the price of bread), education and

\footnotetext{
${ }^{5}$ On the topic of the Italian regional states during the Renaissance, see Andrea Gamberini and Isabella Lazzarini, eds., The Italian Renaissance State (Cambridge: Cambridge University Press, 2012).

${ }^{6}$ The preference of the Gonzaga of Guastalla for the Theatine order had a family connection, for example, as two sons of Ferrante II, Filippo and Giovanni, had entered the Theatines as novices in Naples in 1609. For this reason, Ferrante II, "eager to see them again, made a resolution to give rise in Guastalla to these religious, so that the two novices could make their profession there." Giovanni Gonzaga later became provost general of the order. See Ireneo Affò, Istoria della città e del ducato di Guastalla (Guastalla: Stamperia Salvatore Costa, 1786), 3:110-11.
} 
health policies, and any business affecting the daily life of the urban population. If the duke or the earl at the head of the polity expressed a desire to introduce a religious order such as the Jesuits, the Somascans, the Barnabites, or the Piarists into the state, the city council would have to find the material means for the construction of the school and reach a compromise with the teachers who were already active in the city, as well as managing every material aspect of the arrival of the religious order. These dynamics produced large quantities of documentation, including notarial deeds, correspondence, purchases of material and land, and personal memories, which in many cases are sources of particular interest for the history of religious orders. Very often, however, these documents are scattered in small local archives and are little known to historians. But this does not mean that they are of little value. On the contrary, they are fundamental for the reconstruction of the particular realities with which the congregations interacted.

A great deal of unmined information about the history of religious orders can be found in connection to the smaller regional states, many of which have been neglected and poorly studied because of their small size and peripheral position. Among these, one of the most interesting is the Duchy of Modena, governed by the Estense family from the end of the thirteenth century. ${ }^{7}$ The proper Duchy of Modena, however, only came into existence in 1598, when the territory of Ferrara returned to the direct control of the pope. Thus, from the end of the sixteenth century, this small state included the contemporary provinces of Modena, Reggio Emilia, and part of what is today northwestern Tuscany. Many religious orders found favorable ground for their pastoral activities within its boundaries, and the Jesuits were active in many of its towns and villages.

The oldest foundations occurred before the switchover of the Estense capital from the city of Ferrara to Modena in 1598. The call of the Jesuits to the cities of the dukedom could be determined by different causes. In the city of Modena, for example, a first attempt to establish a Jesuit college was made by the city council in 1552, albeit without great success. A school was opened but soon had to close, although a Jesuit convent remained. Only in the 1590s was a college reopened at the behest of the duke, who foresaw the loss of Ferrara and wanted to open a school for the nobility in his future capital. ${ }^{8}$

\footnotetext{
${ }^{7}$ On the Estense dynasty and the Duchy of Ferrara-Modena, see Trevor Dean, Land and Power in Late Medieval Ferrara: The Rule of the Este, 1350-1450 (Cambridge: Cambridge University Press, 1988), and Luciano Chiappini, Gli Estensi (Rome: Dall'Oglio, 1967).

${ }^{8}$ On the Jesuit presence in early modern Modena, see Olimpia Nuzzi, "Dalla scuola comunale di abaco alla scuoletta dei gesuiti, dalle basse scuole di Francesco III alla scuola elementare dell'Italia unita: La storia dell'alfabetizzazione a Modena," Atti e memorie della deputazione di storia patria per le antiche provincie modenesi 26 (2004): 419-67; and Giuseppe Orlandi, "I religiosi dello stato di Modena nel Settecento tra riforme e rivoluzione," in Lo stato di Modena: Una capitale, una dinastia, una civiltà nella storio d'Europa, ed. Angelo Spaggiari and Giuseppe Trenti (Rome: Ministero per i beni e le attività culturali Direzione generale per gli Archivi, 2001), 743-81. On the
} 
The second foundation did not take place in a city but in a small country town, Novellara, in 1571. This village was nonetheless the capital of a small county, the earl of which wanted the followers of Ignatius within the borders of its polity as an answer to a political and a social need. The call of the Jesuits in the county of Novellara responded to the need to include this small state in a wider cultural and diplomatic network, that of the Society of Jesus, in order to avoid its political extinction at a time when such small political entities no longer had any reason to exist. In doing so, Camillo Gonzaga surprisingly found a way to ensure his state survived for another two centuries. He called the Jesuits within his borders and established a Jesuit convent with a novitiate and a school. Camillo was able to make his small capital an important educational and religious center thanks to the Society of Jesus. Moreover, thanks to the Jesuits' presence, he was also able to insert his dominion into an informal diplomatic network that spanned the four corners of the known world. ${ }^{9}$

After Novellara, the third city in the duchy to host a convent and a Jesuit school was Reggio Emilia, beginning in 1610. Reggio Emilia was the second-largest city in the small Estense state, and here, as in Modena, the Society initially faced opposition to its work. Although the duke gave the Jesuits the local church of San Giorgio, the order's presence was opposed by the city council, which was offended that it had not been consulted about the order's entry into the town. It was only in 1654, thanks to the decisive action of Duke Rinaldo d'Este, that the settlement of the convent was made definitive. ${ }^{10}$ In Reggio Emilia, the Jesuits took care of the education of the laity and the clergy and of evangelization campaigns in the countryside, considered as a land of mission. ${ }^{11}$

The Society's arrival in Reggio was supported by the city having been the birthplace of Alessandro Valla, a priest who became a Jesuit in 1568. Valla, assigned to the Jesuit province of Portugal, had gone to Japan as a missionary sixteen years after the death of Francis Xavier. He was later appointed procurator general

educational situation, see also David Salomoni, Scuola, maestri e scolari nelle comunità degli stati Gonzagheschi e Estensi (Rome: Anicia, 2017); Salomoni, "Pedagogia eretica: Note di ricerca su alcuni processi a maestri di scuola nella Modena del '500," Educazione: Giornale di pedagogia critica 7, no. 2 (2018): 7-32.

${ }^{9}$ On the Jesuit College of Novellara, see David Salomoni, "Le scuole di una comunità emiliana nel Rinascimento tra religione e politica: Il caso di Novellara," Educazione: Giornale di pedagogia critica 5, no. 2 (2016): 17-42; and Sergio Ciroldi, La casa di probazione dei gesuiti di Novellara (Reggio Emilia: n.p., 2011).

${ }^{10}$ Davide Dazzi, "I gesuiti a Reggio Emilia," in Storia della diocesi di Reggio Emilia-Guastalla, vol. 3, Dalla Riforma tridentina alla Rivoluzione Francese, ed. Giovanni Costi and Giuseppe Giovanelli (Brescia: Morcelliana, 2014), 765-94.

${ }^{11}$ Among the Jesuit missionaries active in the rural territory of Reggio Emilia, we find Paolo Segneri and Giovanni Pinamonti, who carried out their missions between 1674 and 1678. See Corrie Norman, "The Social History of Preaching in Italy," in Preachers and People in the Reformations and Early Modern Period, ed. Larissa Taylor (Boston: Brill, 2003), 125-92. 
of the missions of the Far East and Brazil before ultimately dying of the plague in 1580 in Morocco, where he was also taken prisoner during the wars with Portugal. ${ }^{12}$

Another center near Modena where the Jesuits settled was Mirandola, a small city with a prestigious intellectual tradition, including having given birth to humanist Giovanni Pico della Mirandola. The followers of Ignatius arrived in Mirandola in 1611 after being called to the city by the local lord, Alexander I, a descendant of the famous Pico. A college was built, and a local church of Jesus was added by the will of Alexander I on the occasion of his investiture as duke of Mirandola. His intention was to call the most important religious orders of the time to the city. The church was begun in 1621 and completed by Alexander's nephew only in $1689 .^{13}$

After Reggio Emilia, another city where the presence of the Jesuits is linked to the memory of a local member of the Society is the fortified village of Carpi, near Mirandola. Carpi had also been the seat of a small court where arts and culture flourished under the patronage of a dynasty of humanists: the Pio family. ${ }^{14} \mathrm{How}-$ ever, in 1535 Carpi became part of the Duchy of Modena. The Jesuits arrived in this small town in 1622 by order of the duke and later oversaw and administered the public schools as well as preaching in the surrounding countryside. An important figure in determining the Jesuit identity in Carpi was Bernardino Realino. He was born in Carpi in 1530, and after starting his studies in medicine he ultimately graduated in law. In 1564, after a deep existential crisis, he entered the Society of Jesus, welcomed by Alfonso Salmerón, one of the co-founders of the Society, and was sent to Naples where he was ordained priest in 1567. From Naples, he was transferred to Lecce, in southern Apulia, where he established a college and spent most of his time looking after the city's poor. His commitment to the needy was so strong and his memory so important to the inhabitants of Lecce that after his death in 1616 he was named the city's patron saint. The case is unique, since Realino was canonized only in 1947 by Pope Pius XII (r.1939-58). ${ }^{15}$

Last in chronological order among the Jesuit settlements in the Duchy of Modena was the town of Guastalla, in 1728. The Society's arrival in this small town came at a time when the impetus of the new Jesuit foundations was slowing down.

\footnotetext{
12 Dazzi, I gesuiti a Reggio Emilia, 768.

${ }^{13}$ For Mirandola, see Odoardo Rombaldi, "Mirandola dai Pico agli Estensi," in Mirandola e le terre del basso corso del Secchia dal medioevo all'età contemporanea (Modena: Aedes Muratoriana, 1984); and Felice Ceretti, "Della chiesa del Gesù e del collegio dei gesuiti," in Memorie storiche della città e dell'antico Ducato della Mirandola (Mirandola: Tipografia G. Cagarelli, 1891), 44-45. ${ }^{14}$ Giorgio Montecchi, "Istituzioni e forme di comunicazione del sapere: I Pio, la chiesa, la comunità," in Storia di Carpi: La città e il territorio dai Pio agli Estensi (secc. XIV-XVIII), ed. Marco Cattini and Anna Maria Ori (Modena: Mucchi, 2009). See also Charles Bernhard Schmitt, "Alberto Pio and the Aristotelian Studies of His Time," in Società, politica e cultura a Carpi ai tempi di Alberto III Pio (Padua: Antenore Editrice, 1981), 43-64.

${ }^{15}$ Giuseppe Germier, S.J., San Bernardino Realino (Florence: Libreria Editrice Fiorentina, 1944).
} 
Moreover, a large number of other religious orders had been present in the town throughout the early modern age: Benedictines, Augustinians, Observant Franciscans, Capuchins, Theatines, and Servites. Another reason for the late arrival of the Jesuits in Guastalla may have been the rivalry with Novellara, where the Society had been present since 1571. To distinguish itself from the Gonzaga of Novellara, the branch of the Gonzaga dynasty in Guastalla had favored other religious orders. This too could be part of the dynamics of aristocratic distinction. In fact, the arrival of the Jesuits in Guastalla took place at the behest of a private citizen, who in his will left large patrimonial endowments for the opening of a college and a convent, which remained active until 1767. ${ }^{16}$ As in Reggio Emilia and Carpi, however, the moral legacy of the Jesuits in Guastalla was linked to the memory of one of the first followers of Ignatius, born in the small town in 1531, Emerio Bonazzi (De' Bonis), who was one of the first students at the Collegio Romano. He was sent by Ignatius of Loyola first to Naples, then as a preacher to the countryside of Apulia and Lucania, and later, in 1573, to Calabria, to establish the Society of Jesus and open new schools. Emerio was the first Jesuit to permanently exercise the office of missionary in all the territories of the Neapolitan Jesuit province. ${ }^{17}$

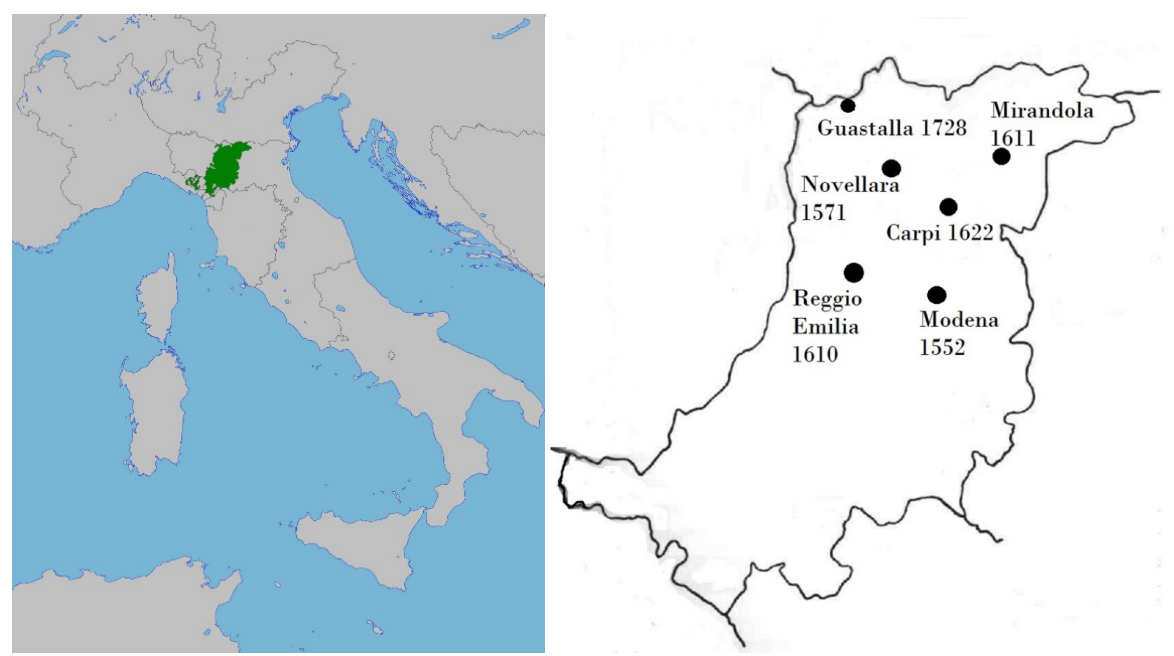

Figures 1-2. Maps of the Duchy of Modena and Jesuit settlements (courtesy of the author).

\footnotetext{
${ }^{16}$ Gino Badini, I gesuiti a Guastalla (Reggio Emilia: La Nuova Tipolito, 2003), and Sergio Ciroldi, "Ordini e congregazioni religiose nel Guastallese," in Costi and Giovanelli, Storia della diocesi di Reggio Emilia-Guastalla, 185-203.

${ }^{17}$ Dazzi, I gesuiti a Reggio Emilia, 768. See also Delle opere del padre Daniello Bartoli della Compagnia di Gesù, vol. 2, Della vita di S. Ignazio (Turin: Tipografia Marinetti, 1825), 98.
} 
Among the various insights that emerge from this picture is the fact that the arrival of the Society of Jesus within these small- and medium-sized settlements was often linked to a member of the community who had previously joined the Jesuit order. This highlights the complexity and implications of memory-building processes. These dynamics are linked to the local identity of each community. The universal dimension of the presence of heavenly protectors who embodied the moral virtues of the Society was linked to the construction of community and local identity in ways that are not very different from the memory of the proto-bishops of the cities of which they became the patrons.

In the short narration reported here, I have listed the main Jesuit foundations within the boundaries of the Duchy of Modena. They were located in the main centers, which is not surprising considering the Jesuits' habit of coming into contact with the ruling classes of the regions where they settled. However, it is clear that the Jesuits did not always find it easy to settle permanently in the cities to which they were called. Local politics could create problems, as seen earlier in the cases of Modena and Reggio Emilia, where the Jesuits never managed to open universities. ${ }^{18}$ The situation was similar in Mantua and Parma, where universities were actually opened but not without the support of the ruling dynasties. ${ }^{19}$ In smaller towns, on the other hand, with weaker municipal institutions, the opposition was generally less threatening.

What emerges from this list of foundations is also the link that the Jesuits usually obtained with the ruling classes. Even when they could not establish a university, the schools that they opened were often elitist boarding schools. These boarding schools were all located in the flatland of the duchy, which was the productive and agricultural heart of the small state. Modena was located in one of the most technologically advanced areas of the world in the field of agricultural sciences. As such, Modena's ruling classes came largely, though not exclusively, from the lowlands, where the Jesuits established their schools. Moreover, if we look at the timeline of these foundations, we can see that almost all of them took place over a period of seventy years, from 1552 to 1622 . The school of Guastalla, which opened in 1728, was the only exception.

As mentioned earlier, the archives of these Jesuit settlements are not institutional ones but are contained in local historical archives (i.e., municipal, ecclesiastical, or state archives). Some documentary collections have remained in

\footnotetext{
${ }^{18}$ Paul Grendler, The Jesuits and Italian Universities 1548-1773 (Washington, DC: Catholic University of America Press, 2017); Grendler, Jesuit Schools and Universities in Europe, 22, 45.

${ }^{19}$ On Parma and Mantua, see, respectively, Cristiano Casalini, "Building a Duchy to the Greater Glory of God: The Jesuits and the Farnesian Educational Policy in Parma (1539-1604)," Educazione: Giornale di pedagogia critica 4, no. 1 (2015): 29-48; Ugo Baldini, "I gesuiti nella cultura del ducato," in Un Borbone tra Parma e l'Europa: Don Ferdinando e il suo tempo, 1751-1802, ed. Alba Mora (Reggio Emilia: Diabasis, 2005), 98-135; and Paul Grendler, The University of Mantua, the Gonzaga, and the Jesuits, 1584-1630 (Baltimore: Johns Hopkins University Press, 2009).
} 
their original locations. In the case of Novellara, for example, most of the funds are still located in the local municipal archives, while in the case of Guastalla there are fewer documents relating to the Jesuit presence as most of the sources have been transported to the State Archives of Parma. ${ }^{20}$

At the time of the Society's suppression in 1773, ownership of part of the archives of the Jesuit colleges of Novellara and Reggio Emilia was taken over by the University of Modena together with all the Jesuits' real estate within the Este territory. In 1774, eighty-three files and seventy-five economic books of the Collegio di Reggio, in addition to fifty-one tomes and sixty-seven economic books of the Collegio di Novellara, arrived in Modena. ${ }^{21}$ This material constitutes the "Suppressed Jesuits Documentary Collection," organized in four volumes by archivist Giovan Battista Wattenhofer. The first volume consists of two books with the inventories of the papers of the colleges of Mirandola and Modena, while the three books of the second volume are dedicated respectively to the colleges of Reggio Emilia, Carpi, and Novellara. In the third and fourth volumes, there is a detailed index by category where the documents are organized according to the subjects. The archivist's careful description of each document suggests that this archival organization was intended to deal with the legal problems following the Society's suppression.

The documents of the Jesuit convent of Guastalla had a different destiny. Today, they are kept in the State Archives of Parma with the other papers from the suppressed Jesuits' convents within the Farnese states. In Parma, the real estate of the Society was taken over by the university. The documentation coming from Guastalla is limited because of the short life of this Jesuit settlement and consists of only five envelopes. In the first, we find documents relating to the foundation of the college with all the most important information relating to its history. There is also an envelope with documents containing the legacies and donations given to the college by private citizens. In Guastalla, however, there are only two major donations, relating to the Filippi and Bertolucci families, while in the case of Reggio

\footnotetext{
${ }^{20}$ Modena State Archives (Archivio di Stato di Modena), Suppressed Jesuits Fund (Fondo Gesuiti Soppressi): strands 1-83; and Jesuit School Assets Fund (Fondo Gesuiti Patrimonio degli Studi). See also Inventario generale dei rogiti, scritture e libri economici ritrovati nell'archivio dei soppressi Gesuiti di Modena, Reggio, Mirandola, Carpi e Novellara, kept in the Eca Fund located in the Modena State Archives. See also Giuseppe Orlandi, "I religiosi dello stato di Modena nel Settecento tra riforme e rivoluzione," in Lo stato di Modena: Una capitale, una dinastia, una civiltà nella storio d'Europa, ed. Angelo Spaggiari and Giuseppe Trenti (Rome: Ministero per i beni e le attività culturali Direzione generale per gli Archivi, 2001), 743-81.

${ }^{21}$ Modena State Archives, Religious Congregations Archival Fund (Fondo Corporazioni religiose), Brescello Ecclesiastico, filing thread no. 3, 1555-70, p. 1069; filing thread no. 4, 3: Compagnia di Gesù, 1327-1773 Suppressed Jesuits Fund (the papers before the founding of the order are private inheritance forfeitures): Collegio di Modena (1327-1773); Collegio di Reggio (1425-1773); Collegio di Carpi (1583-1773); Collegio di Mirandola (1514-1773); Collegio di Novellara (1560-1773).
} 
and Novellara, the amount of bequests and donations is so large that it is often difficult to understand the link between the document and the donor.

If the remaining Jesuit documentation for Reggio Emilia is more characterized by economic and patrimonial aspects, the papers of the Jesuits of Guastalla are more important for the Jesuit correspondence contained therein and for the detailed bibliographic inventories made immediately after the Society's expulsion from the Bourbon States in 1768. However, in the Duchy of Parma the overall reorganization of the material was not as meticulous as would be the case in Modena a few years later. Many documents were arbitrarily dismembered for legal reasons following the Jesuits' expulsion, creating chaos in the organization of the papers. Only at the end of the nineteenth century was an attempt made to reorganize the archives by clumsily trying to re-aggregate the main archive funds.

However, the different locations of these archives should not lead us to believe that such documents can be studied or considered separately from each other. This is the most interesting aspect of the documentation. The Jesuits of the various colleges and houses were constantly in touch with each other, creating a dense network between the Jesuits and the notable people of the local societies in which they worked. Particularly rich, once again, is the Jesuit archive of Novellara, which, as mentioned, is partly preserved in the State Archives of Modena and partly in the municipal archives. The documentation kept in this small center is particularly useful for understanding the peripheral evolution of the Society of Jesus in early modern Italy.

\section{Other Uses}

There are other uses that can be made of these sources in addition to those already mentioned. For example, school documents can be used to better understand students' lives and education as a response to social and material needs. The Jesuit settlement of Novellara, for example, not only housed a college but also a probation house that formed young Jesuits from the surrounding communities. Among the students, we find for a short period Aloysius Gonzaga, the future saint of the Society, before he was sent to the Collegio Romano. ${ }^{22}$ The historical archive of Novellara contains notebooks with the compositions and exercises of both college students and Jesuit novices. ${ }^{23}$

In addition, through the comparative study of Jesuit sources with those of other religious orders active in the same communities, it is possible to deepen our

\footnotetext{
${ }^{22}$ Virgilio Cepari, Vita di San Luigi Gonzaga della Compagnia di Gesù (Milan: Nella Stamperia di Giuseppe Pandolfo Malatesta, 1728), 80, 94.

${ }^{23}$ Municipal Archives of Novellara (Archivio Storico Comunale di Novellara), Gonzaga Fund (Archivio Gonzaga), Section Pious Institutions (Sezione Enti Pii), envelope 194.
} 
knowledge of the interaction between different teaching congregations. In the Duchy of Modena, for example, it is possible to observe the division of the educational market between Jesuits and Piarists. The former, as seen earlier, were rooted in the main commercial and manufacturing centers and settled in the rich irrigated plain of northern Italy. The Piarists, on the other hand, had to settle in the poorest mountain villages, where, nevertheless, the ancient feudal aristocracy aspired to the same social status as the lowland elites. This gave the Piarists an opportunity to earn the trust of the ducal authority of Modena through their service in areas other religious orders often neglected. ${ }^{24}$ This in turn allowed the Piarists to take over even in the rich centers of the lowlands (for example, in the community of Mirandola) when the Society of Jesus was dissolved in the eighteenth century. Another local network that can be compared with that of the Jesuits in the Duchy of Modena is the complex system of settlements of the Capuchin friars, who were also engaged in the educational field, although often within public educational institutions rather than in colleges belonging to their order. ${ }^{25}$

\section{Conclusion}

This essay has aimed to highlight how much the forgotten heart of deeply and widely studied places like the Italian peninsula can still give to research on the Society of Jesus. Here, I have offered only one example of a local network, that of the Duchy of Modena, in which, despite its small size, seven settlements of the order took root between the sixteenth and eighteenth centuries. Although the existence of the duchy's archives is not unknown to historians, their contents have hardly ever gone beyond the limits of local scholarly research and have not really been integrated into the framework of global research into the Society of Jesus.

\footnotetext{
${ }^{24}$ On the Piarists, see Paul Grendler, "The Piarists of the Pious Schools," in Religious Orders of the Catholic Reformation: In Honor of John C. Olin on His Seventy-Fifth Birthday, ed. Richard DeMolen (New York: Fordham University Press, 1994), 252-78; Grendler, Schooling in Renaissance Italy: Literacy and Learning 1300-1600 (Baltimore: Johns Hopkins University Press, 1989), 381-89. See also Alberto Tanturri, "Scolopi e gesuiti all'epoca di S. Giuseppe Calasanzio," Archivio italiano per la storia della pietà 13 (2000): 193-216. For the Piarist schools of Correggio, see Maria Grazia Lasagni, "La presenza degli scolopi a Correggio dal 1722 al 1810," in Istruzione, educazione e collegio in Correggio dal XVII al XX secolo, ed. Alberto Ghidini (Correggio: Convitto Nazionale R. Corso, 1999), 33-80.

${ }^{25}$ Giovanni Moncalieri, Chorographica descriptio provinciarum et conventuum fratrum minorum S. Francisci capucinorum praedicatorum, sacerdotum, clericorum, et lacos universorum eiusdem ordinis collectio (Turin, 1654).
} 